\section{Impact of Soil Moisture and Mowing Height on Ataenius spretulus (Coleoptera: Scarabaeidae) Selection of Golf Course Turf Habitat in Choice Tests}

\author{
Young-Ki Jo and David R. Smitely \\ Department of Entomology, Michigan State University, East Lansing, MI 48824
}

Additional index words. habitat selection, oviposition

\begin{abstract}
Ataenius spretulus (Haldeman) (Coleoptera: Scarabaeidae) is the most common grub in golf course fairways in Michigan. Ataenius spretulus grubs are 3- to 10-fold more abundant in golf course fairways (mowed at a height of $1.5 \mathrm{~cm}$ ) than in the roughs (mowed at a height of $5.0 \mathrm{~cm}$ or higher). Predation and infection by Paenibacillus sp. were previously reported to be greater in the rough, and may partially explain outbreaks of $A$. spretulus grubs in golf course fairways. In addition to natural enemies, cultural practices of irrigation and mowing could also be important factors, especially if $A$. spretulus prefers to oviposit in the fairway over the rough. In this paper we examine the impact of soil moisture and mowing height on oviposition and habitat selection. In a greenhouse experiment where $A$. spretulus adults were given a choice of turf maintained at fairway or rough height, no ovipositional preference for one or the other was observed. In three different growth chamber experiments where adults were allowed to choose among fairway or rough turf plugs held in soil at different moisture levels, adults preferred turf plugs in soil at a volumetric moisture content of $13 \%$ to $26 \%$ over turf plugs in soil at $8 \%$ to $9 \%$ moisture for their habitat selection. We conclude from these greenhouse and growth chamber experiments that $A$. spretulus adults do not choose turf habitat based on mowing height, but may be influenced by soil moisture levels.
\end{abstract}

Ataenius spretulus (Haldeman)(Coleoptera: Scarabaeidae) has been found in 41 states and is reported to cause damage on golf course turf in at least 23 states of the U.S. (Cartwright, 1974; Weaver and Hacker, 1978; Wegner and Niemczyk, 1979; Wegner and Niemczyk, 1981). In Michigan, A. spretulus is the most abundant white grub in golf course fairways, and golf course superintendents consistently list A. spretulus grubs as one of their most serious insect pest problems (Rothwell and Smitley, 1999; Smitley et al., 1998).

Ataenius spretulus instars are typical-looking c-shaped white grubs. Full-grown third instars of $A$. spretulus ( $8.5 \mathrm{~mm}$ long) resemble late first instar larvae of larger turfgrass scarabaeids, such as European chafer (Rhizotrogus majalis Razoumowsky) and Japanese beetle (Popilliajaponica Newman). Ataenius spretulus grubs consume roots of many species of cultivated turfgrass (Vittum et al., 1999). The root damage results in increased susceptibility to environmental stresses, particularly drought. A combination of grub injury and environmental stresses weakens turfgrass in small irregular patches, eventually leading to large dead areas (Vittum, 1995).

Turf damage by $A$. spretulus grubs is usually found on golf course fairways mowed at a

\footnotetext{
Received for publication 23 Oct. 2005. Accepted for publication 20 Dec. 2005. We thank Terry Davis and Deborah Miller for technical support, Drs. Joseph Vargas Jr., Douglas Landis, Leah Bauer and James Crum for their guidance and suggestions, and Dr. Ned Walker and Kadir Kizilaya for helping with data analyses. This research was supported by the Michigan Turfgrass Foundation.

${ }^{1}$ To whom reprint requests should be addressed; e-mailsmitley@msu.edu.
}

height of about $1.5 \mathrm{~cm}$, but not on golf course roughs or home lawns mowed at a height of 5.0 $\mathrm{cm}$ or more. The density of $A$. spretulus grubs is 3 - to10-fold higher in fairways than roughs in golf courses (Smitley et al., 1998). This difference has been observed even in the first meter of the rough which receives a similar amount of irrigation and fertilization as the fairway. A higher density of predatory insects and a higher incidence of Paenibacillus sp.-infection of grubs in the rough compared with the fairway suggest that natural enemies play an important role in suppressing A. spretulus grubs in golf courses (Jo and Smitley, 2003; Rothwell and Smitley, 1999; Smitley and Rothwell, 2003).

In addition, environmental factors may affect the habitat selection and oviposition behavior of $A$. spretulus adult beetles. Turfgrass species, soil type, insecticides and fungicides were found not to be primary factors contributing to the high density of $A$. spretulus grubs in fairways compared with roughs (Rothwell and Smitley, 1999; Smitley and Rothwell, 2003). However, mowing practices and soil moisture could also influence the distribution of $A$. spretulus in golf course turf, and these factors have not yet been evaluated (Jo and Smitley, 2003; Rothwell and Smitley,1999). The specific objective of this project is to use greenhouse and growth chamber experiments to evaluate how soil moisture and grass height impact habitat selection and ovipositional preference of $A$. spretulus in fairway and rough turf.

\section{Materials and Methods}

Collection of A. spretulus adult beetles. Ataenius spretulus adult beetles used in this study were collected at Royal Scot GolfCourse, Lansing, Mich., in 1999 and 2000. Beetles were handpicked off the smooth surface of creeping bentgrass (Agrostis stolonifera L.) putting greens. The collected beetles were temporarily stored in petri dishes with a layer of moisturized filter paper and used for the experiment within $12 \mathrm{~h}$ of collection. After sex differentiation according to Wegner and Niemczyk (1979), males and females were released at a 1:1 ratio.

Greenhouse experiment. Perennial ryegrass (Lolium perenne L.) turf was established in a section of the Food Safety Greenhouse Range at Michigan State University, East Lansing (20 to $25{ }^{\circ} \mathrm{C}$ of mean daily temperature; $15.2-\mathrm{h}$ average day length for June and July). Perennial ryegrass was seeded at a rate of $9 \mathrm{~g} \cdot \mathrm{m}^{-2}$ in plastic nursery pots $(15 \times 15 \times 20 \mathrm{~cm})$ filled with loamy sand soil $(85.9 \%$ sand, $9.9 \%$ silt and $4.2 \%$ clay; $\mathrm{pH} 6.5$ ). Two levels of mowing height were established by hand clipping twice a week. Fairway-type turf was maintained to the height of $1.5 \mathrm{~cm}$ and rough-type turf to the height of $5.0 \mathrm{~cm}$. The same amount of water (daily) and fertility $\left(0.8 \mathrm{~g} \cdot \mathrm{L}^{-1}\right.$ of $20 \mathrm{~N}-20 \mathrm{P}-20 \mathrm{~K}$ fertilizer; biweekly) were applied to both fairway and rough turf.

Four turf (two fairway and two rough, alternated) pots bound tightly together using duct tape (3M Center, St. Paul, Minn.) were considered an experimental plot. Ten experimental plots were established on the greenhouse bench. Forty A. spretulus adult beetles were introduced into each plot on 8 June 1999. Rims of each pot facing inside were cut down to the soil level, allowing introduced beetles to move across all four turf pots. After the beetles were released, each plot was covered with a removable fine-net cage. Watering, fertility and clipping were maintained as before. Forty-five days after beetle release, thatch and soil in the turf pots were visually examined and third instars of $A$. spretulus were counted. The experiment was a completely randomized design with 10 replications and the effect of mowing height on the incidence of $A$. spretulus third instars was tested with a one-way analysis of variance (ANOVA) using PROC GLM (SAS Institute, 1996).

Growth chamber experiments. Three different experiments (Experiments A, B, and C) with soil moisture levels were conducted in a growth chamber $\left(25^{\circ} \mathrm{C} ; 60 \%\right.$ relative humidity; 12:12 L:D) between 13 August 1999 and 17 July 2000. One, two, or four levels of soil moisture were prepared for each experiment as follows: volumetric soil moisture (the volume of water per unit volume of soil) was adjusted to $17 \%$ $(-10 \mathrm{kPa})$ for the single-moisture experiment (Experiment A); 9 and 23\% (-600 $\mathrm{kPa}$ and -5 $\mathrm{kPa}$, respectively) for the two-moisture experiment (Experiment B); and 8\%, 13\%, 20\%, and $26 \%(-700,-50,-6$, and $-3 \mathrm{kPa}$, respectively) for the four-moisture experiment (Experiment C). Steam-sterilized loamy sand soil (87.4\% sand, 9.2\% silt, and 3.4\% clay; $\mathrm{pH} 7.1$ ) was used in this study. The physical properties of the soil were as follows: $1.41 \mathrm{~g} \cdot \mathrm{cm}^{-3}$ bulk density; $46 \%$ volumetric soil moisture for the saturation point; $26 \%$ for the field capacity $(-3 \mathrm{kPa})$; and 
A

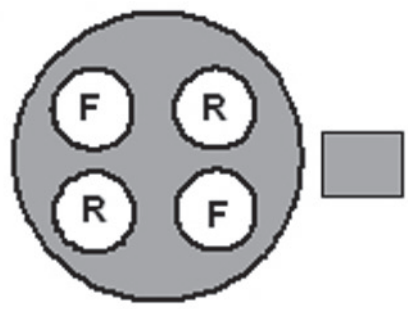

$17 \%$

C
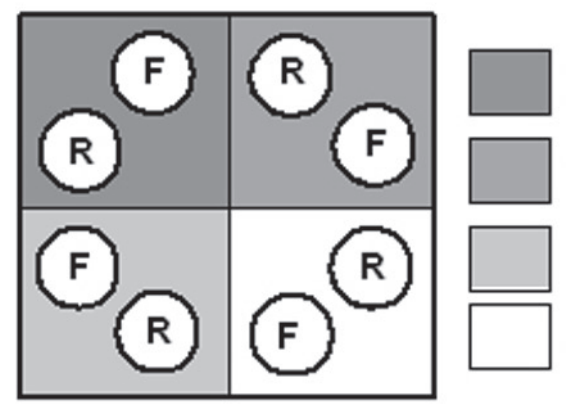

$26 \%$

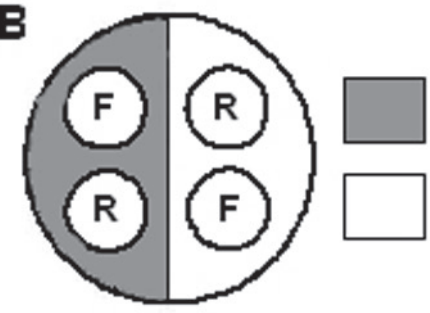

$23 \%$

$9 \%$

Fig. 1. Illustration of experimental plots established in a growth chamber for evaluating the habitat selection and ovipositional preference of Ataenius spretulus adults in moist or dry soil, and fairway $(1.5 \mathrm{~cm} \mathrm{high)}$ or rough (5.0 cm high) turf plugs. Four turf plugs were maintained at one volumetric soil moisture (\%) level for Experiment A (A), four turf plugs were maintained at two soil moisture levels for Experiment B (B) and eight turf plugs were maintained at four soil moisture levels for Experiment C (C).

$6 \%$ for the wilting point $(-1,500 \mathrm{kPa})$. Turfplugs ( $2 \mathrm{~cm}$ in diameter, $4 \mathrm{~cm}$ deep) were removed from the mixture of $80 \%$ annual bluegrass (Poa annua raptans $\mathrm{L}$.) and $20 \%$ creeping bentgrass at the Hancock Turfgrass Research Center, East Lansing, and replanted in previously prepared soils at various moisture levels. The mowing height and thatch depth of turf plugs were 1.5 and $1.5 \mathrm{~cm}$ for the fairway, and 5.0 and $3.0 \mathrm{~cm}$ for the rough, respectively. Soil in this research field is Owosso-Marlette sandy loam, pH 7.5 and the soil of turf plugs contains $61.2 \%$ sand, $27.4 \%$, silt and $11.4 \%$ clay.

Plots for Experiment A were established in plastic pots $(10 \mathrm{~cm}$ in diameter, $15 \mathrm{~cm}$ deep) filled with soil at the volumetric moisture content of $17 \%$ and implanted with turf plugs. Two fairway and two rough plugs were alternatively planted in each plot (Fig. 1A). In Experiment $\mathrm{B}$, plastic pots ( $10 \mathrm{~cm}$ in diameter, $15 \mathrm{~cm}$ deep) were divided in the middle by impermeable plastic sheets. Each half of the pot was filled with soil at the volumetric moisture content of $9 \%$ or $23 \%$ and planted with one fairway and one rough plug (Fig. 1B). Plots for Experiment $\mathrm{C}$ consisted of four plastic pots $(10 \times 10 \mathrm{~cm})$, which were filled with soils at one of four different moisture levels: $8 \%, 13 \%, 20 \%$, or $26 \%$. One fairway and one rough plug were planted in each pot. Pots were pushed together and bound tightly without any gap between them. Theinside rims contacting other pots were removed down to the soil surface level to allow free movement of insects across pots.

Plots were tightly sealed with plastic bags to equilibrate moisture between soil and turf plugs for $12 \mathrm{~h}$ before initiating the experiment. Fifteen $A$. spretulus adult beetles were introduced into each plot for Experiments A and B, and 20 adults for Experiment C. After release, plots were covered with a pin-holed transparent plastic bag for containing the beetles. Seven days after beetles were introduced, turf plugs were examined under a dissecting microscope and A. spretulus adults, eggs and first instar larvae were counted.

To maintain soil moisture during the experiment, water lost due to evapotranspiration was estimated using control plots and was replaced daily. The control plot was exactly the same as each experimental plot except no A. spretulus adult beetles were introduced. Water loss was determined by collecting soil samples from the control plots daily, weighing the samples immediately after removal, and weighing again after drying them in an oven at $105^{\circ} \mathrm{C}$. The calculated percent soil moisture could then be compared with the original, and the appropriate amount of water added to make up for any that was lost during the experiment.

Treatment replications were arranged in a completely randomized design for these experiments. One trial of Experiment A with 10 replications was conducted from 13 to 20 Aug. 1999; two trials of Experiment B with 10 replications between 24 Aug. and 11 Sept. 1999; and four trials of Experiment $\mathrm{C}$ with five replications between 20 May and 17 July 2000. The effect of turf type on the recovery of A. spretulus adults, eggs and first instars was analyzed using a one-way ANOVA for Experiment A. The effects of soil moisture and turf type were analyzed using two-way ANOVA for Experiments B and C. In Experiment C, soil moisture effects were compared using contrasts. Also, since $A$. spretulus adults were collected and used for the experiments at sequential time periods between 13 Aug. 1999 and 17 July 2000, time effect on the recovery of first instar larvae and eggs in each sample period was evaluated using a one-way ANOVA.

If any eggs or first instar larvae were found in turf plugs, all of the soil in the plots was then examined for additional eggs and larvae, using a semi-automatic elutriator(Byrd etal., 1976) and sugar floatation (Jenkins, 1964). Soil samples were filtered through $850-\mu \mathrm{m}$ coarse-steel and then $75-\mu \mathrm{m}$ fine-steel screens by the elutriator. Mixtures of eggs, larvae and other debris caught in the fine screen were put into centrifuge tubes filled with a sugar solution $(2 \mathrm{M})$ and centrifuged at 2,500 revolutions per minute (rpm) for 10 min. During centrifugation, eggs and larvae sunk, while lighter materials floated. After the supernatant liquid was discarded, pure water was added into the sediment and centrifuged at 2,500 rpm for $10 \mathrm{~min}$. Eggs and larvae floating on the supernatant were collected and counted under a dissecting microscope. To ensure the efficacy of this procedure, the control run was performed twice using $400 \mathrm{~mL}$ soil mixture with 20 A. spretulus eggs.

\section{Results}

Greenhouse experiment. There was no significant difference in the abundance of $A$. spretulus third-instars found in fairway turf compared with rough turf in the greenhouse experiment $(\mathrm{F}=0.01 ; \mathrm{df}=1,18 ; P=0.94)$. The mean number of recovered third-instars was 2.7 \pm 0.8 (SEM) in the fairway turf and $2.6 \pm 1.1$ (SEM) in the rough turf per plot. The number

Table 1. The percent recovery (mean \pm SEM per plot) of Ataenius spretulus adults, $7 \mathrm{~d}$ after introducing them into the center of two or four fairway $(1.5 \mathrm{~cm}$ high) and rough $(5.0 \mathrm{~cm}$ high) turf plugs held at various soil moisture levels.

\begin{tabular}{|c|c|c|c|c|c|}
\hline \multirow[b]{2}{*}{ Experiment } & \multirow{2}{*}{$\begin{array}{c}\text { Mowing } \\
\text { ht }\end{array}$} & \multicolumn{4}{|c|}{ Volumetric soil moisture (\%) } \\
\hline & & $8-9$ & 13 & $17-20$ & $23-26$ \\
\hline A1 & Fairway & & & $26.7 \pm 5.1$ & \\
\hline \multirow[t]{2}{*}{ B1 } & Rough & & & $30.7 \pm 2.8$ & \\
\hline & Fairway & $11.1 \pm 3.7$ & & & $27.3 \pm 3.9$ \\
\hline \multirow[t]{2}{*}{ B2 } & Rough & $11.9 \pm 2.5$ & & & $26.0 \pm 6.1$ \\
\hline & Fairway & $18.4 \pm 2.7$ & & & $15.2 \pm 3.0$ \\
\hline \multirow[t]{2}{*}{$\mathrm{C} 1$} & Rough & $6.8 \pm 1.7$ & & & $28.4 \pm 4.3$ \\
\hline & Fairway & $1.2 \pm 0.5$ & $4.5 \pm 0.5$ & $5.0 \pm 1.6$ & $3.0 \pm 0.5$ \\
\hline \multirow[t]{2}{*}{$\mathrm{C} 2$} & Rough & $3.0 \pm 0.5$ & $4.5 \pm 0.5$ & $4.0 \pm 1.0$ & $4.5 \pm 1.7$ \\
\hline & Fairway & $3.7 \pm 0.5$ & $8.5 \pm 1.0$ & $5.5 \pm 0.9$ & $5.0 \pm 0.8$ \\
\hline \multirow[t]{2}{*}{$\mathrm{C} 3$} & Rough & $3.5 \pm 0.6$ & $5.5 \pm 1.5$ & $4.0 \pm 0.6$ & $6.5 \pm 1.0$ \\
\hline & Fairway & $2.1 \pm 0.5$ & $4.0 \pm 0.6$ & $4.5 \pm 0.9$ & $4.0 \pm 0.9$ \\
\hline \multirow[t]{3}{*}{$\mathrm{C} 4$} & Rough & $3.0 \pm 0.5$ & $4.0 \pm 0.6$ & $5.5 \pm 0.9$ & $6.5 \pm 1.0$ \\
\hline & Fairway & $2.0 \pm 0.9$ & $4.0 \pm 0.6$ & $3.5 \pm 1.0$ & $5.0 \pm 0.8$ \\
\hline & Rough & $3.5 \pm 0.6$ & $3.0 \pm 1.5$ & $5.0 \pm 1.6$ & $7.0 \pm 0.9$ \\
\hline
\end{tabular}


Table 2. ANOVA statistics for testing habitat-selection of Ataenius spretulus adults, $7 \mathrm{~d}$ after introducing them into the center of two or four fairway and rough turf plugs held at various soil moisture levels.

\begin{tabular}{|c|c|c|c|c|}
\hline Experiment & Source of variation & $\mathrm{F}$ & df & $P$ \\
\hline$\overline{\mathrm{A} 1}$ & Moisture & 0.47 & 1,18 & 0.5000 \\
\hline \multirow[t]{3}{*}{ B1 } & Moisture & 12.19 & 1,36 & 0.0013 \\
\hline & Mow & 0.001 & 1,36 & 0.9962 \\
\hline & Moisture $\times$ Mow & 0.10 & 1,36 & 0.7515 \\
\hline \multirow[t]{3}{*}{ B2 } & Moisture & 7.77 & 1,36 & 0.0084 \\
\hline & Mow & 0.06 & 1,36 & 0.8098 \\
\hline & Moisture $\times$ Mow & 14.12 & 1,36 & 0.0006 \\
\hline \multirow[t]{4}{*}{$\mathrm{C} 1$} & Moisture & 2.74 & 3,32 & 0.0598 \\
\hline & Mow & 0.71 & 1,32 & 0.4069 \\
\hline & Moisture $\times$ Mow & 0.92 & 3,32 & 0.4423 \\
\hline & $8 \%$ vs. $13 \%$ to $26 \%^{\mathrm{a}}$ & 7.41 & 1,32 & 0.0104 \\
\hline \multirow[t]{4}{*}{$\mathrm{C} 2$} & Moisture & 5.03 & 3,32 & 0.0057 \\
\hline & Mow & 1.54 & 1,32 & 0.2242 \\
\hline & Moisture $\times$ Mow & 2.20 & 3,32 & 0.1076 \\
\hline & $8 \%$ Vs. $13 \%$ to $26 \%$ & 8.98 & 1,32 & 0.0052 \\
\hline \multirow[t]{4}{*}{$\mathrm{C} 3$} & Moisture & 5.45 & 3,32 & 0.0038 \\
\hline & Mow & 4.39 & 1,32 & 0.0442 \\
\hline & Moisture × Mow & 0.97 & 3,32 & 0.4173 \\
\hline & $8 \%$ vs. $13 \%$ to $26 \%$ & 13.17 & 1,32 & 0.0010 \\
\hline \multirow[t]{4}{*}{$\mathrm{C} 4$} & Moisture & 3.54 & 3,32 & 0.0254 \\
\hline & Mow & 1.83 & 1,32 & 0.1858 \\
\hline & Moisture × Mow & 0.84 & 3,32 & 0.4830 \\
\hline & $8 \%$ vs. $13 \%$ to $26 \%$ & 4.61 & 1,32 & 0.0395 \\
\hline
\end{tabular}

${ }^{\mathrm{a}}$ Comparison of $8 \%$ with $13 \%$ to $26 \%$ soil moisture levels using a contrast $\left(\mathrm{C}=3 \mu_{1}-\mu_{2}-\mu_{3}-\mu_{4}\right)$.

of grubs recovered was low, given that $40 \mathrm{~A}$. spretulus adult beetles were introduced, partly due to difficulty in visually counting first and second instars in turf root zone.

Growth chamber experiments. Soil moisture levels remained within the observed range for each treatment during the experiment and affected the habitat selection of $A$. spretulus adult beetles. However, turf type did not affect the habitat selection of the beetles. More adults were recovered from turf plugs held in soil containing $13 \%$ to $26 \%$ moisture than in soil containing $8 \%$ to $9 \%$ moisture regardless of turf type (Tables 1 and 2). In the single-moisture experiment, similar numbers of adults were found in fairway and rough plugs (Tables 1 and 2, ExperimentA). When adults were given a choice between $23 \%$ and $9 \%$ soil moisture, they preferred turf plugs with $23 \%$ soil moisture in both trials (Tables 1 and 2, Experiment B). Given a choice of four soil moisture levels, soil moisture but not turf type was significant for habitat-selection of adult beetles in all four trials (Tables 1 and 2, Experiment C). When $8 \%$ was compared with $13 \%$ to $26 \%$ soil moisture, adults preferred turf plugs in soil with $13 \%$ to $26 \%$ moisture over soil with $8 \%$ moisture in all four trials (Table 2, Experiment C).

When A. spretulus adults were added to experimental turf plots, time of year was a significant factor in the recovery of $A$. spretulus eggs $(\mathrm{F}=4.96 ; \mathrm{df}=6,28 ; P=0.002)$ and first
Soil moisture but not mowing height influenced the habitat selection of $A$. spretulus adults.

In greenhouse experiments, there was no difference in the number of $A$. spretulus adults or grubs found in perennial ryegrass turf clipped to fairway or rough height. This suggests that mowing height itself does not explain field observations of a greater abundance of $A$. spretulus grubs in the fairway compared with the rough. Recent studies of the distribution of $A$. spretulus on golf courses in Wisconsin indicated that the percent organic matter of the soil may also affect the density of $A$. spretulus grubs (Williamson et al., 2005). However, percent organic matter in the soil cannot explain how the density of $A$. spretulus grubs increased in golf course plots when the mowing height was changed from rough height to fairway height, but the density of grubs decreased when the mowing height was changed from fairway height to rough height, over a 2-year period (Rothwell and Smitley 1999). In our growth chamber experiment, we also could not detect any preference of $A$. spretulus adult beetles for habitat-selection on fairway or rough turf, which has different organic matter contents due to a difference in the thickness of the thatch layers in fairway (1.5 $\mathrm{cm})$ and rough turf $(3.0 \mathrm{~cm})$. Natural enemies are still the most likely factors that account for the difference in the density of $A$. spretulus in golf course fairways and roughs as our previous report (Jo and Smitley, 2003).

In the growth chamber experiments, two- to three-fold more adults selected turf plugs held in moist soil ( $13 \%$ to $26 \%$ moisture) compared with dry soil ( $8 \%$ to $9 \%$ moisture), regardless of turf type. This preference for selecting moist soil or avoidance of dry soil was consistent throughout experiments conducted at various times and could indirectly contribute to an ovipositional preference for fairways where soil moisture is sometimes greater than in the rough. This is consistent with pervious reports that soil moisture affects the incidence of other turfgrass scarabaeids. Flight and oviposition of May or June beetles (Phyllophaga crinita Burmeister) is followed by rainfall (Gaylor and Frankie, 1979); and southern masked chafer (Cyclocephala immaculata Olivier), Japanese beetle and rose chafer (Macrodactylus subspinosus F.) lay more eggs in moist soil than in dry soil (Allsopp et al., 1992; Potter, 1983). Although A. spretulus adults seem to prefer moist soils regardless of turf type, we cannot conclude from these experiments that there is any ovipositional preference for moist soil over dry soil, mainly because of the lack of observed oviposition.

Table 3. Ataenius spretulus eggs and first instar larvae ${ }^{\mathrm{z}}$ recovered from turf plugs.

\begin{tabular}{|c|c|c|c|c|c|}
\hline \multirow[b]{2}{*}{ Date } & \multirow{2}{*}{$\begin{array}{l}\text { Mowing } \\
\text { ht }\end{array}$} & \multicolumn{4}{|c|}{ Volumetric soil moisture (\%) } \\
\hline & & $8-9$ & 13 & $17-20$ & $23-26$ \\
\hline \multirow[t]{2}{*}{30 May-6 June 2000 (Expt. C2) } & Fairway & 0 & 0 & 0 & 0 \\
\hline & Rough & 0 & 0 & 23 eggs & 0 \\
\hline 15-22 June 2000 (Expt. C3) & Rough & 10 eggs, 41 larvae & 15 eggs, 29 larvae & 9 larvae & 36 eggs, 24 larvae \\
\hline \multirow[t]{2}{*}{ 10-17 July 2000 (Expt. C4) } & Fairway & 0 & 0 & 3 larvae & 9 larvae \\
\hline & Rough & 0 & 0 & 8 larvae & 9 larvae \\
\hline
\end{tabular}

${ }^{2}$ Ataenius spretulus eggs or first instar larvae were not found on 13-20 Aug. (Expt. A1), 24-31 Aug. (Expt. B1) and 4-11 Sept. (Expt. B2) in 1999, and 20-27 May (Expt. C1) in 2000. 
Even though the edge of the fairway and the first $1.0 \mathrm{~m}$ of rough receive a similar amount of irrigation, soil moisture levels may still be less in the rough because the taller turf and larger root system uses more water. Because we found that $A$. spretulus has some preference for turf and soil with high moisture levels, it may be worthwhile in the future to measure the soil moisture levels along the edge of the fairway and rough to see how much they differ. It is possible that the taller $(5.0 \mathrm{~cm}$ or higher) turfgrass in the rough tends to dry the soil more quickly than the turf in the fairway, despite the fact that the rough-side and the fairway-side of the rough/fairway border receive about the same amount of water (Biran et al., 1981; Madison and Hagan, 1962). This may result in somewhat drier soil conditions in roughs than fairways and could influence habitat selection, which eventually leads to increased oviposition of $A$. spretulus females in golf course fairway turf. We cannot say how likely this is from our study. This hypothesis needs to be investigated with field studies where $A$. spretulus eggs are extracted from soil in late June to determine where females lay the most eggs. Extraction of $A$. spretulus eggs using a semi-automatic elutriator and sugar floatation gives a high efficiency of recovery $(70 \%)$ in this study and can be used in field studies as well.

Outside of our focus on the preference of A. spretulus adult beetles for soil moisture and mowing height, the continuous collection of A. spretulus adults from the same golf course (Royal Scot Golf Course) throughout much of the year gives us some information about their life cycle. One or sometimes a partial second generation of $A$. spretulus per year has been reported in New England, New York and Michigan (Smitley et al., 1998; Vittum, 1995). These reports are more observational than experimental, and there are few data to support them, mainly because of the difficulty of rearing $A$. spretulus in the lab and recovering its eggs and larvae. The artificial conditions of the turf in our growth chamber assays differs substantially from turf on a golf course, so the physiology or behavior of our beetles could have changed after they were collected from the field and put under laboratory conditions. However, it is important to point out that our attempt was the first ovipositional assays using field-collected $A$. spretulus adult beetles throughout the season and ovipositional activities were observed within 7-d of when beetles were collected. The result from our laboratory experiment indicating that the peak ovipositional period of A. spretulus in central Michigan is in late June needs to be confirmed with additional laboratory assays using A. spretulus adult beetles collected from different locations and by the serial field collection of eggs and first instar larvae from May to September.

\section{Literature Cited}

Allsopp, P.G., M.G. Klein, and E.L. McCoy. 1992. Effect of soil moisture and soil texture on oviposition by Japanese beetle and rose chafer (Coleoptera: Scarabaeidae). J. Econ. Entomol. 85:2194-2200.

Biran, I., B. Bravdo, I. Bushkin-Harav, and E. Rawitz. 1981. Water consumption and growth rate of 11 turfgrasses as affected by mowing height, irrigation frequency, and soil moisture. Agron. J. 73:85-90.

Byrd, Jr., D.W., K.R. Barker, H. Ferris, C.J. Nusbaum, W.E. Griffin, R.H. Small, and C.A. Stone. 1976. Two semi-automatic elutriators for extracting nematodes and certain fungi from soil. J. Nematol. 8:206-212.

Cartwright, O.L. 1974. Ataenius, Aphotaenius, and Pseudataenius of the United States and Canada (Coleoptera: carabaeidae: Aphodiinae). Smithsonian Contrib. Zool. 154:1-106.

Gaylor, M.J. and G.W. Frankie. 1979. The relationship of rainfall to adult flight activity; and of soil moisture to oviposition behavior and egg and first instar survival in Phyllophaga crinita. Environ. Entomol. 8:591-594.

Jenkins, W.R. 1964. A rapid centrifugal-flotation technique for separating nematodes from soil. Plant Dis. Rpt. 48:692.
Jo, Y.-K. and D.R. Smitley. 2003. Predation of Ataenius spretulus (Coleoptera: Scarabaeidae) eggs and grubs by species of Carabidae and Staphylinidae on golf courses in Michigan. Environ. Entomol. 32:1370-1376.

Madison, J.H. and R.M. Hagan. 1962. Extraction of soil moisture by Merion bluegrass (Poa pratensis $\mathrm{L}$. 'Merion') turf, as affected by irrigation frequency, mowing height, and other cultural operations. Agron. J. 54:157-160.

Potter, D.A. 1983. Effect of soil moisture on oviposition, water absorption, and survival of southern masked chafer(Coleoptera: Scarabaeidae) eggs. Environ. Entomol. 12:1223-1227.

Rothwell, N.L. and D.R. Smitley. 1999. Impact of golf course mowing practices on Ataenius spretulus (Coleoptera: Scarabaeidae) and its natural enemies. Environ. Entomol. 28:358-366.

SAS Institute. 1996. SAS/STAT user's guide. version 6. SAS Inst., Cary, N.C.

Smitley, D.R., T.W. Davis, and N.L. Rothwell. 1998. Spatial distribution of Ataenius spretulus, Aphodius granarius (Coleoptera: Scarabaeidae), and predaceous insects across golf course fairways and roughs. Environ. Entomol. 27:1336-1349.

Smitley, D.R. and N.L. Rothwell. 2003. How the use of chlorothalonil on golf courses impacts Paenibacillus sp., a pathogen of Ataenius spretulus (Coleoptera: Scarabaeidae). J. Econ. Entomol. 96:792-797.

Vittum, P.J. 1995. Black turfgrass ataenius, p. 35-37. In: R.L. Brandenberg and M.G. Villani (eds.). Handbook of turfgrass insect pests. Entomol. Soc. Amer., Lanham, Md.

Vittum, P.J., M.G. Villani, and H. Tashiro. 1999. Turfgrass insects of the United States and Canada. Cornell Univ. Press, Ithaca, N.Y.

Weaver, J.E. and J.D. Hacker. 1978. Bionomical observations and control of Ataenius spretulus in West Virginia. W.Va. Univ. Agr. For. Expt. Sta. Curr. Rpt. 72.

Wegner, G.S. and H.D. Niemczyk. 1979. The Ataenius of Ohio. Ohio J. Sci. 79:249-255.

Wegner, G.S. and H.D. Niemczyk. 1981. Bionomics and phenology of Ataenius spretulus. Ann. Entomol. Soc. Amer. 74:374-384.

Williamson, R.C., A.T. Walston, and D. Soldot. 2005. Influence of organic-based fertilizers and root zone mixes on the incidence of black turfgrass ataenius (Coleoptera: Scarabaeidae) infestations on golf courses. Intl. Turfgrass Soc. Res. J. 10:803-810. 